\title{
MULTICRITERIA ANALYSIS FOR IDENTIFYING FOREST FIRE RISK ZONES IN THE BIOLOGICAL RESERVE OF THE SAMA CORDILLERA, BOLIVIA
}

\author{
S. Mariscal ${ }^{1}$, M. Ríos ${ }^{1}$, F. Soria ${ }^{1 *}$ \\ ${ }^{1}$ Centro de Investigación en Agua, Energía y Sostenibilidad, Department of Environmental Engineering, Universidad Católica \\ Boliviana “San Pablo", La Paz, Bolivia - freddy.soria@ucb.edu.bo
}

KEY WORDS: Protected area, Difference Normalized Burn Index.

ABSTRACT:

Forest fires have negative effects on biodiversity, the atmosphere and human health. The paper presents a spatial risk model as a tool to assess them. Risk areas refer to sectors prone to the spread of fire, in addition to the influence of human activity through remote sensing and multi-criteria analysis. The analysis includes information on land cover, land use, topography (aspect, slope and elevation), climate (temperature and precipitation) and socio-economic factors (proximity to settlements and roads). Weights were assigned to each in order to generate the forest fire risk map. The investigation was carried for a Biological Reserve in Bolivia because of the continuous occurrence of forest fires. Five risk categories for forest fires were derived: very high, high, moderate, low and very low. In summary, results suggest that approximately $67 \%$ of the protected area presents a moderate to very high risk; in the latter, populated areas are not dense which reduces the actual risk to the type of events analyzed.

\section{INTRODUCTION}

Protected areas have an important value for the conservation and preservation of ecosystems within a framework of sustainable development. Management plans of the Biological Reserve of Sama Cordillera in Bolivia (RBCS) indicate that forests at this protected area (PA) are periodically affected by fires of great intensity. As a result, grasslands and rivers are as well affected by the ashes, generating negative impacts on the aquatic flora and fauna. In turn, water pollution can deteriorate the health of the surrounding communities and the population of Tarija city (Artunduaga et al., 2004)

An effective alternative to cope with fires is through prevention (Soares, 1985). For such purposes, it is necessary to identify areas with different degrees of fire risk in order to carry out an effective prevention plan (Andrade et al. 2011), as a countermeasure against fire frequency damage avoidance (Jaiswal et al. 2002). For this reason it is important to find sites with a high risk of forest fires inside the RBCS

In order to improve risk management measures of forest fires, it is important to understand relevant site factors and its evolution (Tedim, Carvalho, 2013). The use of satellite data to map and identify areas vulnerable to forest fires help to minimize the frequency of fires and thus avoid damage (Jaiswal et al., 2002). Geographic Information Systems (GIS) contribute to associate the variables that integrate the determinants of fire behaviour for the generation of cartographic products useful for forest protection actions and emergency decision making (Andrade et al., 2011).

\section{METHODS AND MATERIALS}

\subsection{Study Area}

The RBCS is located in Tarija-Bolivia. It has an area of approximately $1085 \mathrm{~km}^{2}$. Within the reserve were identified 207 species of birds, 57 species of mammals, 23 species between reptiles and amphibians, 4 species of fish, and 83 species between arthropods, annelids and mollusks.

\subsection{Methodology}

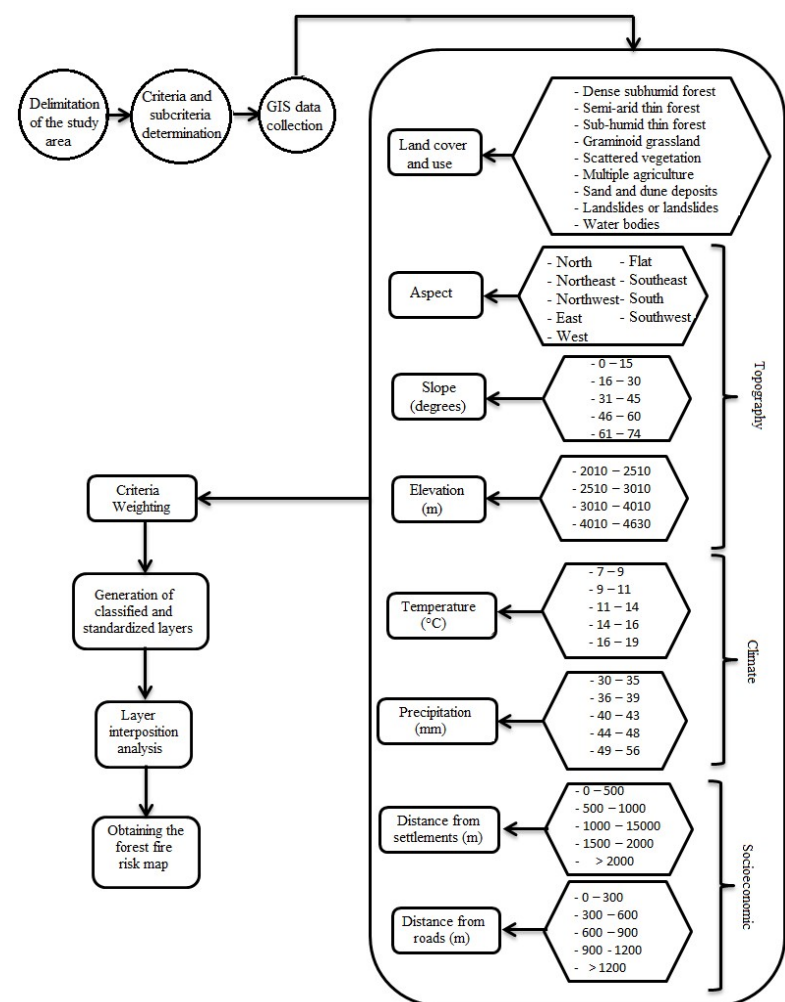

Figure 1. Summary of the methodology

The multicriteria analysis applied is summarized in Figure 1. It gathers concepts, approaches, models and methods, as an aid to decision making based on the description, evaluation, order and

* Corresponding author 
selection of factors, based on an evaluation. Decisions are taken through evaluations, values or intensities of preference according to various factors, such as objectives, reference values, or usefulness (Moraga, 2010). The analysis can be applied to identify adequate options, classify all alternatives or to evaluate different criteria (Dodgson et al., 2009).

Multicriteria analysis, combined with remote sensing and GIS techniques, is a widely used approach to model forest fire risks (Gigović et al., 2018). The assessment is considered useful due to the fact that it has a visual scope of geographical reference that leads to a comprehensive analysis of elements such as socioeconomic and biophysical factors. Compared to other ground observation systems (such as direct observation or aerial photography), this method provide a global view at different scales which simplifies the analysis of information in regions not visible to the spectrum (Martínez-Vega et al., 2010).

Finally, the Difference Normalized Burn Index (NBR) is used to standardize the final products. The NBR index is used as an additional measure to assess the damage caused by forest fires or to analyse the regeneration capacity and evolution of vegetation after the occurrence of fire events (Bodí et al., 2012). The NBR provides an aid to identify areas with vegetation growth after the fire, areas that were not burned, and areas burned with different levels of severity (Bodí et al., 2012).

\subsubsection{Analysis and data interpretation}

\section{Data sources}

Data was obtained from public access servers. Geo Bolivia (https://geo.gob.bo/portal/) provided most of the data; the projection system is WGS 84 . The following data was collected from that mentioned server: National Protected Areas maps (SERNAP, 2014), land use and land cover maps (UTNIT, 2010), road network (ABC, 2017), local communities (INE, 2012). In addition, the $30 \mathrm{~m}$ resolution Digital Elevation Model corresponds to NASA's Shuttle Radar Topography Mission (Rodriguez et al., 2006) (https://lpdaac.usgs.gov/tools/earthdata-search/), temperature and precipitation from year 2000 correspond to the Geospatial and Farming Systems Consortium Server, WorldClim - Global Climate Data (Fick, Hijmans, 2017). Regarding satellite imagery, it correspond to Landsat 8 July 26th and August 25 th, 2017 , May 21st and July $2^{\text {nd }}, 2019$, obtained from Earth Engine platform.

\section{Land cover and land use}

It is one of the most important parameter affecting fire occurrence and fire spread (Rather et al., 2018). Within this element, classification was accomplished according to its flammability and vulnerability to fires; classes were weighted according to Chavan et al. (2012).

Soil information was classified within a range of 1 to 5 , according to the forest fire vulnerability level (Table 1; Figure 2). Thus, a weight of 5 was assigned to forested vegetation due to the high risk to fire in comparison to other types of vegetation, such as thickets, grasslands or pastures (Rather et al., 2018); likewise, forests grasslands and non-dense vegetation have a weight of 4 , agricultural areas have a weight of 3 , and drier areas (which include sand, dunes and erosive areas) have a weight of 2 because of the low risk to fires; water bodies have a value of 1 (Luiz de Sá de Oliveira, 2013).

\begin{tabular}{|l|c|c|}
\hline \multicolumn{1}{|c|}{ Classes } & Weight & Classification \\
\hline Water bodies & 1 & Very low \\
Sand and dune deposits; landslides & 2 & Low \\
Agriculture & 3 & Moderate \\
Grassland; scattered vegetation & 4 & High \\
Dense sub humid forest; semi-arid thin & 5 & Very high \\
forest; sub-humid thin forest & & \\
\hline
\end{tabular}

Table 1. Land cover and land use weighting

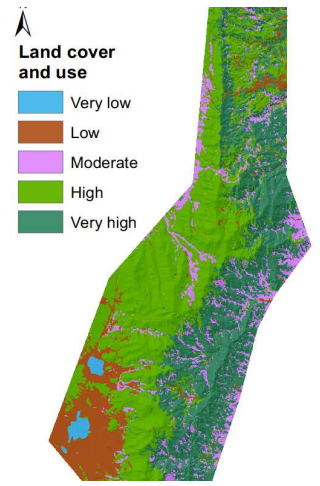

Figure 2. Weighted land use-land cover map

\section{Climate}

The relationship between climate and forest fires is based on the moisture content of soil and vegetation (Muñoz et al. 2005). Although fires can occur at any temperature, their frequency has a certain level of dependence on temperature increase or reduction (Gigović et al., 2018). High temperatures lead to dry vegetation, which imply higher risk to fire (Rather et al., 2018). Precipitation is an important factor as well, due to the influence it has on the humidity of the air, habitat and flammability; the ignition capacity of a sector can vary based on the moisture in the atmosphere due to precipitation. A wet medium has higher influence at the beginning of a fire event and the spread of fire; on the other hand, if soils or vegetation are dry, fire will spread faster. With this criterion, annual average values of temperature and precipitation were classified in five ranges and weighted according the vulnerability level to fires (Table 2). Figure 3 displays the mapped criteria.

\begin{tabular}{|c|c|c|c|}
\hline \multicolumn{2}{|c|}{ Classes } & \multirow{2}{*}{ Weight } & \multirow{2}{*}{ Classification } \\
\cline { 1 - 2 } Precipitation (mm) & Temperature $\left({ }^{\circ} \mathrm{C}\right)$ & & Very low \\
\hline $49-56$ & $7-9$ & 1 & Low \\
$44-48$ & $9-11$ & 2 & Moderate \\
$40-43$ & $11-14$ & 3 & High \\
$36-39$ & $14-16$ & 4 & Very high \\
$30-35$ & $16-19$ & 5 & . \\
\hline
\end{tabular}

Table 2. Weighting for climate data 

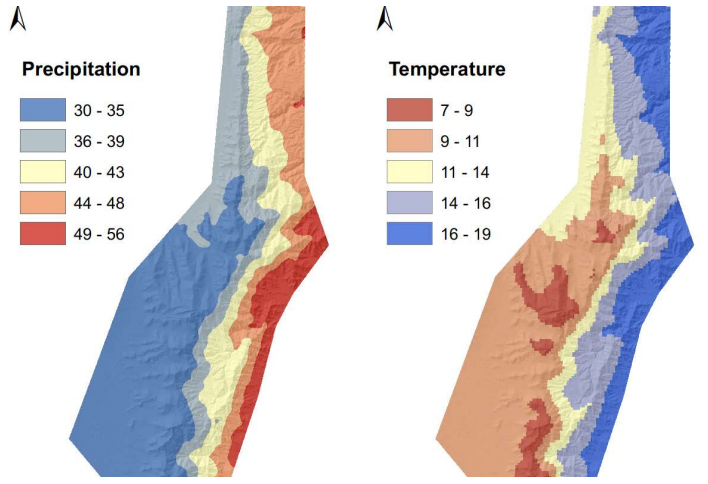

Figure 3. Weighted climate maps

\section{Topography}

Topography is related to wind, sun exposure and humidity, because of which it should be expected an influence on fire spreading (Jaiswal et al., 2002). Three sub-criteria were considered: aspect, slope and elevation. Aspect influences solar radiation intensity that reaches the ground, in turn affecting air humidity and the flammability of the available matter (Luiz de Sá de Oliveira, 2013); aspect also provides a relationship between terrain, sunlight and wind (Jaiswal et al., 2002). Slope influences forest fires as it affects the spread of fire (Adab et al., 2011); the highest the slope, the more the flames bend and the fire area expands (Luiz de Sá de Oliveira, 2013). Elevation is associated with wind trends, temperature, precipitation and the spread of fire (Gigović et al., 2018; Rather et al., 2018); it influences vegetation, the humidity of the material and air humidity, for instance it is of interest for the kind risk being analysed (Adab et al., 2011). As a result, five vulnerability levels were weighted for aspect based on Gigović et al. (2018); slope and elevation were weighted on five levels as well, based on the vulnerability (Table 3; Figure 4).

\begin{tabular}{|c|c|c|c|c|}
\hline \multicolumn{3}{|c|}{ Classes } & Weight & Classification \\
\hline Aspect & $\begin{array}{c}\text { Slope } \\
\text { (degrees) }\end{array}$ & $\begin{array}{c}\text { Elevation } \\
(\mathrm{m})\end{array}$ & & \\
\hline North & $0-15$ & $4010-4630$ & 1 & Very low \\
Northeast; & $16-30$ & $3510-4010$ & 2 & Low \\
Northwest & & & & \\
East; West & $31-45$ & $3010-3510$ & 3 & Moderate \\
Southeast & $46-60$ & $2510-3010$ & 4 & High \\
South; & $61-74$ & $2010-2510$ & 5 & Very high \\
Southwest & & & & \\
\hline
\end{tabular}

Table 3. Weighting according to the topographic data
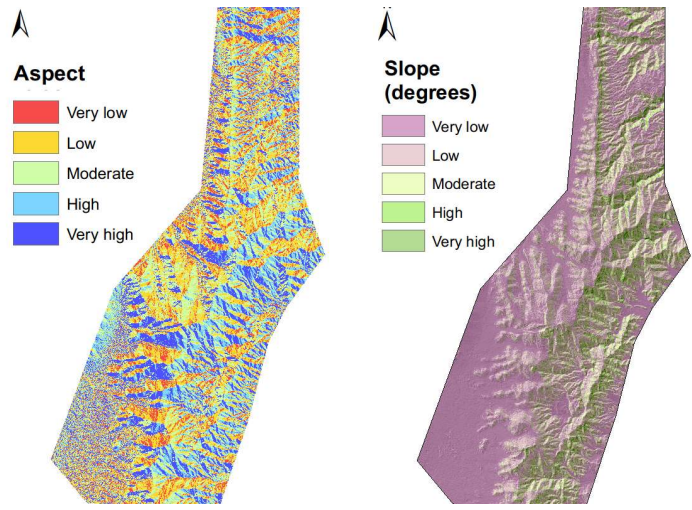

Figure 4. Weighted maps of aspect and slope

\section{Socioeconomic factors}

The proximity to settlements is important since human activities are often related to fire occurrence (Chavan et al., 2012; Gigović et al., 2018; Rather et al., 2018). Roads which cross forested areas are useful for fire fighting because they facilitate access to firemen equipment, which accelerates the process of fire control, minimizing the damage caused (Martell, 2007). Nevertheless, the accessibility of humans to areas near roads causes them to be a cause of fire occurrence due to the influence of anthropogenic activities (Gupta, Nair, 2012). In turn, the air flow created by vehicular circulation is another factor likely to increase the spread of fire (Rather et al., 2018).

For the analysis, buffer distances were considered for roads and settlements, which led to five distance ranges. According to that criteria (i.e., the closer distances have a higher risk level), the weighs considered are described in Table 4 . Figure 3 presents maps constructed under the criteria referred to aspect, elevation and distance from settlements.

\begin{tabular}{|c|c|c|c|}
\hline \multicolumn{2}{|c|}{ Classes } & \multirow{2}{*}{ Weight } & Classification \\
\cline { 1 - 2 } $\begin{array}{c}\text { Distance from } \\
\text { roads }(\mathrm{m})\end{array}$ & $\begin{array}{c}\text { Distance from } \\
\text { settlements }(\mathrm{m})\end{array}$ & & \\
\hline$>1200$ & $>2000$ & 1 & Very low \\
$900-1200$ & $1500-2000$ & 2 & Low \\
$600-900$ & $1000-1500$ & 3 & Moderate \\
$300-600$ & $500-1000$ & 4 & High \\
$0-300$ & $0-500$ & 5 & Very High \\
\hline
\end{tabular}

Table 4. Weighting for socioeconomic data
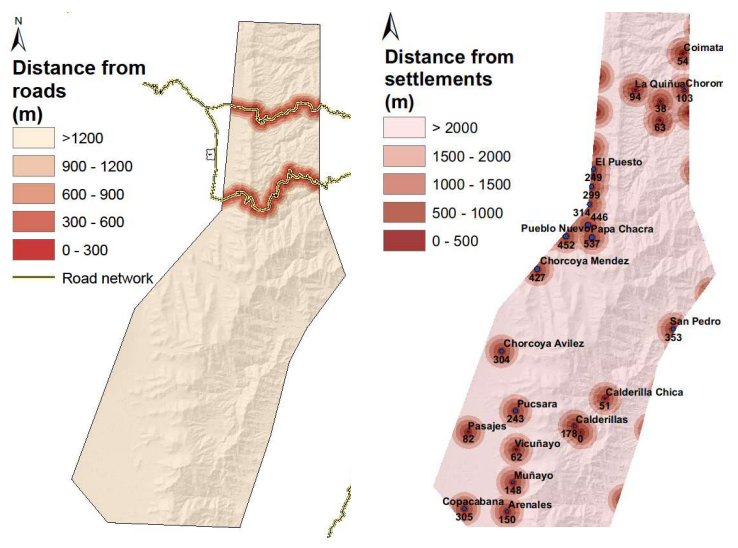

Figure 5. Weighted socioeconomic maps 


\subsubsection{Sub criteria integration}

In order to determine the risk of forest fires, the sub criteria described in previous paragraphs were integrated through the valuation assigned to each one. Map algebra was used to sum up the sub-criteria according to their corresponding risk percentage. Next, the resulting map was standardized to construct forest fire risk maps. The weighting values shown in Table 5 follow the criteria of Gigović et al. (2018). Resulting maps are presented in Figure 4.

\begin{tabular}{|c|c|c|}
\hline Criteria & Sub criteria & Weight \\
\hline Topography & Aspect & 0.623 \\
& Slope & 0.239 \\
& Elevation & 0.138 \\
& & \\
Climate & Temperature & 0.750 \\
& Precipitation & 0.250 \\
& & \\
Socioeconomic & Distance from settlements & 0.250 \\
& Distance from roads & 0.750 \\
\hline
\end{tabular}

Table 5. Weights for sub criteria integration
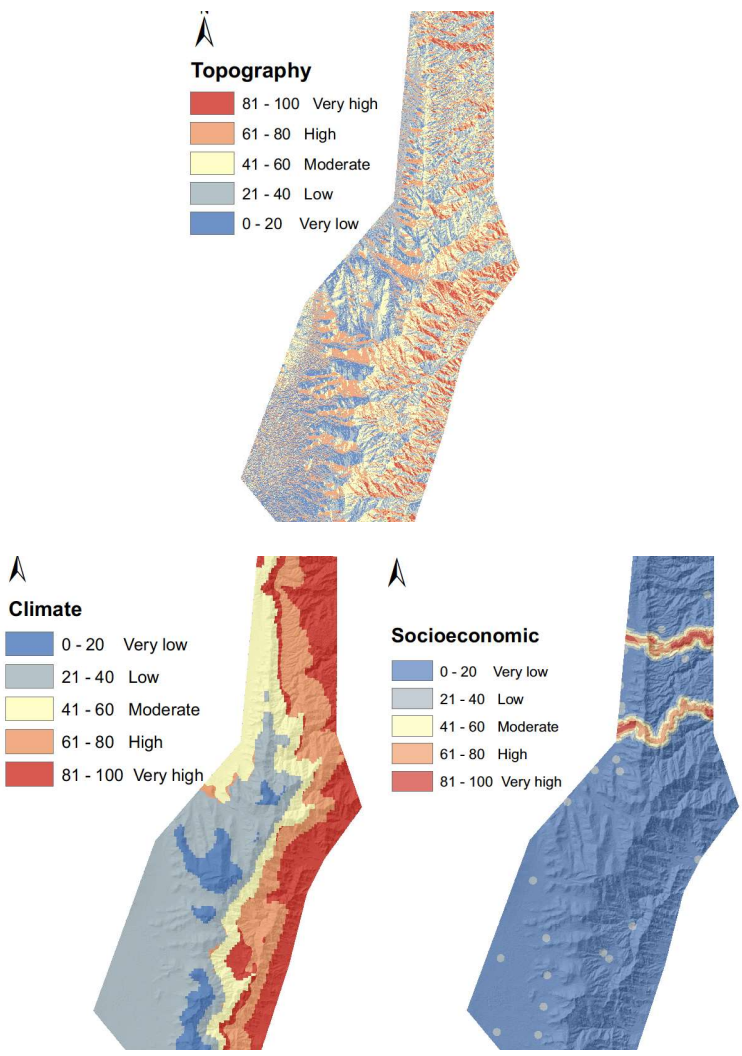

Figure 6. Maps of sub criteria integration

\section{RESULTS AND DISCUSSION}

Table 6 shows the weighting criteria used in the generation of the forest fire risk map. All values were assigned according to Gigović et al. (2018). The highest weights were assigned to land use and land cover because they define the flammability of the material. The next level corresponds to the socioeconomic criteria, due to its high influence on fire ignition after the potential impacts of human behaviour. The topographic and climate criterion define the next levels. Then, to obtain the final forest fire risk map, all the criteria were integrated based on their weighting, resulting in the map shown in Figure 5. Table 6 and Table 7 show the risk classification used in the final map.

\begin{tabular}{|c|c|}
\hline Criteria & Weight \\
\hline Land cover and use & 0.450 \\
Socioeconomic & 0.321 \\
Topography & 0.142 \\
Climate & 0.087 \\
\hline
\end{tabular}

Table 6. Criteria weights for fire risk map

\begin{tabular}{|c|c|c|}
\hline Classification & Area $\left(\mathrm{Km}^{2}\right)$ & Area percentage (\%) \\
\hline Very low & 79.4 & 7 \\
Low & 270.2 & 25 \\
Moderate & 561.3 & 52 \\
High & 162.7 & 15 \\
Very high & 11.2 & 1 \\
\hline
\end{tabular}

Table 7. Fire risk areas

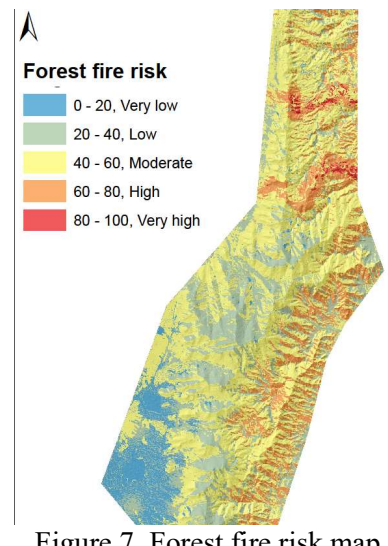

Figure 7. Forest fire risk map

\subsection{NBR}

An additional classification was applied to determine if areas previously affected by fires coincide with the areas that were estimated to have high risk to forest fires (Table 8). The superposition of the NBR index map to the forest fire risk map (Figure 6), identifies NBR areas which intersect with the fire risk levels. Resulting maps shows that the most significant fires occurred within the study area in years 2002, 2017 and 2019.

\begin{tabular}{|c|c|}
\hline Range & Classification \\
\hline$<(-0.25)$ & High growth of vegetation after fire \\
\hline$(-0.25)$ to $(-0.10)$ & Low growth of vegetation after fire \\
\hline$(-0.10)$ to 0.10 & Stable or unburned areas \\
\hline 0.10 to 0.27 & Burned areas with low severity \\
\hline 0.27 to 0.44 & $\begin{array}{c}\text { Burned areas with moderate to low } \\
\text { severity }\end{array}$ \\
\hline 0.44 to 0.66 & $\begin{array}{l}\text { Burned areas with moderate to high } \\
\text { severity }\end{array}$ \\
\hline$>0.66$ & Burned areas with high severity \\
\hline
\end{tabular}

Table 8. NBR Index values 


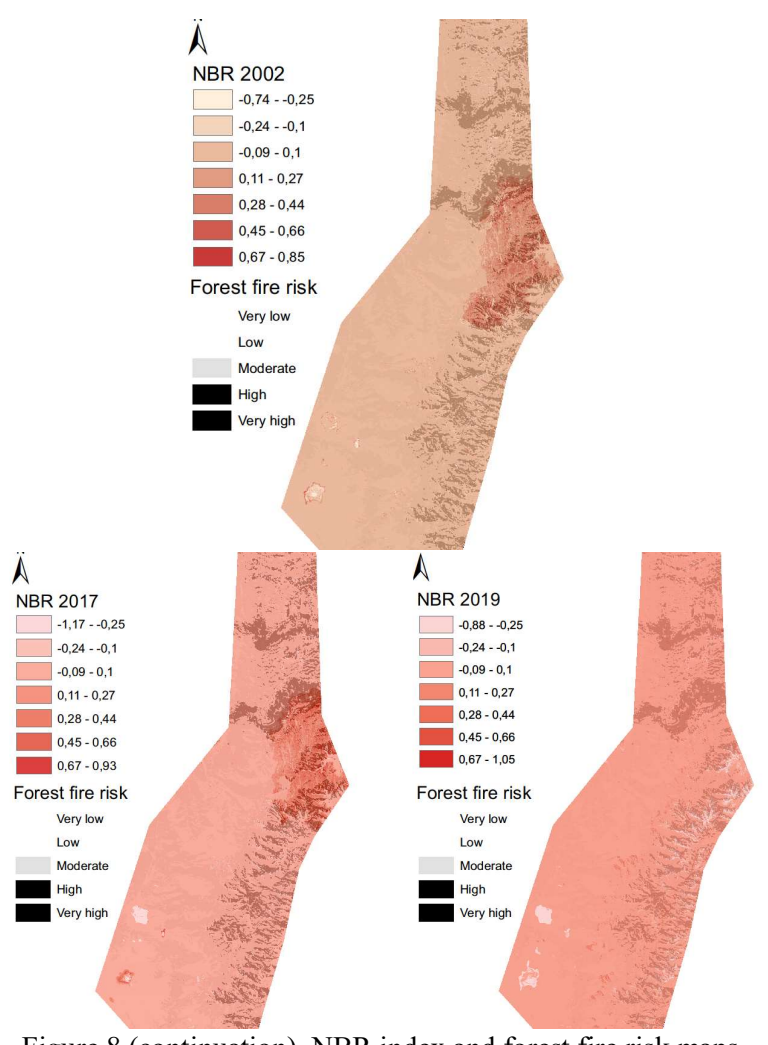

Figure 8 (continuation). NBR index and forest fire risk maps

\subsection{Risk of communities to forest fires}

\begin{tabular}{|c|c|c|}
\hline Classification & Community & Population \\
\hline Low risk & Calderilla Chica & 51 \\
& La Quiñua & 94 \\
& Choroma & 103 \\
& Muñayo & 148 \\
& Arenales & 150 \\
& Pucsara & 243 \\
& Copacabana & 305 \\
& TOTAL POPULATION & 1094 \\
& & \\
Moderate risk & Calderilla grande & 0 \\
& Cochas & 38 \\
& Vicuñayo & 62 \\
& Tres morros & 63 \\
& Pasajes & 82 \\
& Puesto grande & 101 \\
& Calderillas & 178 \\
& El puesto & 249 \\
& Chorcoya Avilez & 304 \\
& Chilcayo & 314 \\
& San Pedro de Sola & 353 \\
& Chorcoya Mendez & 427 \\
& Papa Chacra & 446 \\
& Pueblo Nuevo & 452 \\
& Quebrada grande & 537 \\
& TOTAL POPULATION & 3606 \\
& & \\
& Coimata & 54 \\
& Sama & 299 \\
& TOTAL POPULATION & 353 \\
\hline
\end{tabular}

Table 9. Population of communities within each risk level areas

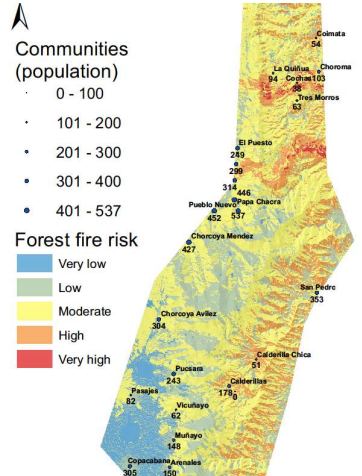

Figure 9. Communities and forest fire risk map

Population data from the National Census of year 2012 was carried in order to obtain an approximate data of the population in 2018. The aim was to estimate the population which live in the different levels of fire risk inside the RBCS. The calculated averages are shown in Table 9 and Figure 7.

\section{CONCLUSIONS}

The forest fire risk map shows that high and very high risk levels exist in $16 \%$ of the total RBCS area. On the other side, most of the surface has a moderate level of risk $(52 \%$ of the area). Although the surface area seems small in value, it should be considered that those zones are very close to the sectors which present a high or very high level of risk, which implies that they can also be harmed since they have similar characteristics.

When performing maps superposition, the areas with high growth of vegetation after the fire occurrence are located nearby the areas with a high level and very high risk of forest fires. In turn, it can be noted that burned areas with high severity are located nearby areas with a moderate and high level of risk.

Based on the comparison of communities inside the RBCS and the forest fire risk map, it can be determined that nearby areas with very high risk and very low risk, few settlements are found. It was also determined that approximately 1094 people live in low risk areas; however, most of the settlements of the RBCS are located in areas with a moderate fire risk. In areas with a higher level of risk, there are only two populations with a total of 353 residents.

\section{REFERENCES}

ABC, 2017. Red fundamental de Bolivia. Gerencia Nacional Técnica de la Administradora Boliviana de Carreteras (ABC), La Paz.

Adab, H., Kanniah, K., Solaimani, K., 2011. GIS-based probability assessment of fire risk in grassland and forested landscapes of Golestan Province, Iran. International Conference on Environmental and Computer Science, IPCBEE, 19, 170-175.

Andrade, C., Ribeiro, G., Gleriani, J., Martins, M., 2011. Uso de fotografias aéreas não convencionais e SIG na elaboração de mapas de risco de incêndios florestais. Anais XV Simpósio Brasileiro de Sensoriamento Remoto - SBSR, 7918-7925. 
Bodí, M., Cerdà, A., Solera, J., Doerr, S., 2012. Efectos de los incendios forestales en la vegetación y el suelo en la cuenca mediterránea: revisión bibliográfica. Boletín de la Asociación de Geógrafos Españoles, (58), 33-56.

Chavan, M., Das, K., Suryawanshi, R., 2012. Forest fire risk zonation using remote sensing and GIS in Huynial watershed, Tehri Garhwal district, UA. International Journal of Basic and Applied Research, 2(7), 6-12.

Dodgson, J., Spackman, M., Pearman, A., Phillips, L., 2009. Multi-criteria analysis: a manual. Department for Communities and Local Government, London, UK.

Fick, S., Hijmans, R., 2017. Worldclim 2: New 1-km spatial resolution climate surfaces for global land areas. International Journal of Climatology, (37), 4302-4315.

Gigović, L., Jakovljević, G., Sekulović, D., Regodić, M., 2018. GIS Multi-Criteria Analysis for Identifying and Mapping Forest Fire Hazard: Nevesinje, Bosnia and Herzegovina. Tehnički vjesnik, 25(3), 891-897.

Gupta, A., Nair, S., 2012. Managing Fire and Pests in Forestry: Approach to Ecosystem Health. In Ecosystem Approach to Disaster Risk Reduction. National Institute of Disaster Management, New Delhi.

INE, 2012. Centros poblados de Bolivia. Instituto Nacional de Estadística (INE), La Paz.

Jaiswal, R., Mukherjee, S., Raju, K., Saxena, R., 2002. Forest fire risk zone mapping from satellite imagery and GIS. International Journal of Applied Earth Observation and Geoinformation, 4(1), 1-10.

Luiz de Sá de Oliveira, A., 2013. Modelagem espacial de predição de riscos de incêndios com lógica fuzzy, comparação e validação. Master's Thesis, Universidade Federal de Pernambuco, Recife, Brazil.

Martell, D., 2007. Forest fire management. In Handbook of operations research in natural resources. Eds. Weintraub, A., Romero, C., Bjørndal, T., Epstein, R. Springer, New York.

Martínez-Vega, J., Martín, M., Díaz Montejo, J., López Vizoso, J., Muñoz Recio, F., 2010. Guía Didáctica de Teledetección y Medio Ambiente. Red Nacional de Teledetección Ambiental, Madrid.

Moraga, J., 2010. Evaluación del riesgo ante incendios forestales en la cuenca del Río Tempisque, Costa Rica. Revista Geográfica de América Central, 2(45), 33-64.

Muñoz, C., Treviño, E., Verástegui, J., Jiménez, J., Aguirre, O., 2005. Desarrollo de un modelo espacial para la evaluación del peligro de incendios forestales en la Sierra Madre Oriental de México. Investigaciones Geográficas, (56), 101-117.

Rather, M., Farooq, M., Meraj, G., Dada, M., Sheikh, B., Wani, I., 2018. Remote Sensing and GIS Based Forest Fire Vulnerability Assessment in Dachigam National Park, North Western Himalaya. Asian Journal of Applied Sciences, (11), 98114.
Rodriguez, E., Morris, C., Belz, J., 2006. A global assessment of the SRTM performance. Photogramm. Eng. Remote Sens., (72), 249-260.

SERNAP, 2014. Mapa de áreas protegidas, Bolivia. Servicio Nacional de Áreas Protegidas (SERNAP), La Paz.

Soares, R., 1985. Incêndios florestais. Controle e uso do fogo. Fundaçao de Pesquisas Florestais do Paraná, Curitiba.

Tedim, F., Carvalho, S., 2013. Vulnerabilidade aos incêndios florestais: reflexões em torno de aspetos conceptuais e metodológicos. Territorium, (20), 85-99.

UTNIT, 2010. Mapa de cobertura y uso actual de la tierra. Unidad Técnica Nacional de Información de la Tierra (UTNIT), La Paz. 